\title{
A Phantom Menace? Patents And The Communal Status Of Space
}

\author{
Tim Smith ${ }^{*}$
}

This paper provides an analysis of the interaction between the most important intellectual property right for the space industry, patents, and the international status of space as a "common area". It suggests that the conventional thesis upon which the application of domestic patent laws to space-based activities rests is an incomplete analysis of the legal interaction. A fundamental conflict between patent rights over inventions that make use of the intrinsic properties of the space environment is identified, and the implications of this conflict discussed. While the application of domestic patent law to space-based activities is nonetheless almost certainly legitimate as a matter of international law, this paper argues that the combined effect of States' patent grants over spacebased inventions is to undermine the status of space as a "common area".

\section{INTRODUCTION}

Now with a permanent human presence in space aboard the International Space Station, the practical benefits to mankind are almost infinite. Not only will there be new advances in space technology, but there will be a chance for all types of different scientific fields to have new theories tested and experiments completed in microgravity. ${ }^{1}$

Although the National Aeronautics and Space Administration ("NASA") might be accused of a certain self-interest in its proclamation of the benefits of a multi-billion dollar space station, its assessment of the benefits of space utilisation are generally accepted, albeit occasionally in more pragmatic terms. ${ }^{2}$ Pragmatic language is, however, reasonably rare in the field of space resource

* This article is an edited version of a paper submitted in fulfilment of the requirements of the LLB(Hons) degree at the Victoria University of Wellington, 2002.

1 National Aeronautics and Space Administration [NASA] Website <http://spaceflight.nasa.gov/ station/benefits/index.html> (last accessed 3 August 2001).

2 See, for example of more neutral commentary, Roy Gibson Space (Clarendon Press, Oxford, 1992) 144: "there are undoubted benefits to be claimed for space and potentially many more to come". 
development. Space literature, particularly that of the legal community, is filled with effusive rhetoric proclaiming the benefits of space utilisation for humanity. ${ }^{3}$

However, in the last two decades the precise mechanism by which humanity will receive the benefits of space utilisation has altered remarkably. Since 1984 the international space-faring community, led by the United States of America, has sought to facilitate the commercialisation of space utilisation. To take but one example, the International Space Station, perhaps the flagship of a new era in humanity's utilisation of space, has as its priority goal the "economic development of Earth orbital space". ${ }^{4}$

The motivation of the space-faring States to "open up" to private commercial interests an area that has hereto been almost exclusively the province of States is obvious. Space exploration and research is a massively expensive enterprise. In 2002 alone, NASA anticipated a US\$2.1 billion expenditure on the International Space Station, out of a total budget of US\$14.7 billion. In the face of such figures, States have increasingly looked to private investment to provide funding for space program development.

However, as for Earth-bound activities, "industry expects protection of its research and development investment which may cover a range from simple recovery of the initial investment, up to protecting future fruits of the investment". 5 The particular nature of protection industry expects will, of course, depend on the nature of the enterprise. With no immediate prospect of mining celestial bodies, the most important space-based enterprises in the present era of space exploitation are likely to involve the utilisation of the space environment itself for research purposes. The first fruits of investment in the current space program will not be space-based minerals but rather intellectual. As such, the primary method by which space investors will create new economic value is through the creation of intellectual property. ${ }^{6}$

3 See, for example, Declaration of Legal Principles Governing the Activities of States in the Exploration and Use of Outer Space (13 December 1963) General Assembly Resolution XVIII, preamble; Resolution adopted by the Third United Nations Conference on the Exploration and Peaceful Uses of Outer Space (30 July 1999), preamble <http://www.oosa.unvienna.org/unisp-3/res/html/viennadecl.html $>$ (last accessed 20 August 2002); Ty S Twibell "Space Law:Legal Restraints on Commercialisation and Development of Outer Space" (1997) 65 UMKC LR 590, 619.

4 Commercial Space Act Pub L No 105-303 (1998).

$5 \quad$ B L Smith "An Industry Perspective on Space-Related Intellectual Property Rights" (September 1995) 15 ECSL News $<$ http://esapub.esrin.esa.it/ecsl/ecs115/ecs115sm.htm> (last accessed 29 September 2002).

6 Marguerite Broadwell "Intellectual Property and the Economic Development of the International Space Station" (Speech to the Space Technology and Applications International Forum, Albuquerque, February 2000) $2<$ http://commercial.hq.nasa.gov/files/staifpapers/intellectual_property.pdf $>$ (last accessed 29 September 2002). 
This paper is concerned with the creation of intellectual property in space, not by specific inventors, but by the States which extend their intellectual property laws to cover space-based activities. Such coverage is essential to the creation of economic value through space-based research because the intellectual property derived from such research is unlikely to be able to be exploited on Earth. Space-based research is incredibly expensive, ${ }^{7}$ and therefore tends to involve aspects of the space environment that are not reproducible on Earth. As such, for intellectual property rights to be effective, space-based activities must be made subject to them.

The creation of intellectual property rights in space involves the creation of personal property rights in an area not within the territory of any particular State, but rather an international area common to all. As such, any application of domestic law in such an area must necessarily be judged against the international law governing State conduct in respect of the area. This paper suggests that there is a fundamental theoretical conflict between intellectual property rights, and in particular patent grants, and the international status of space as an area common to all States. While this conflict does not manifest itself as a legal breach of States' international obligations, in practical reality, intellectual property rights as currently enforced undermine the status of space as an area common to all.

The development of the commercial International Space Station means that space is now "open for business" for the generation of private intellectual property rights over space-based activities. Given the importance attached to the commercialisation of space by the international community, it is appropriate to consider now whether the new era in space exploitation is built on a proper foundation.

II THE CONVENTIONAL THESIS OF INTELLECTUAL PROPERTY RIGHTS IN SPACE

\section{A Intellectual Property Rights}

"Intellectual property rights" describe a diverse array of personal property rights that exist over intangible "intellectual" creations. As defined by the Convention Establishing the World Intellectual Property Organisation, intellectual property includes, inter alia, rights relating to "literary, artistic and scientific works" and "inventions in all fields of human endeavour". 8

In the context of the commercialisation of outer space, the most important intellectual property rights are the industrial forms of intellectual property; the forms of intellectual property that provide

7 See, for example of the United States of America's pricing structure for commercial use of research elements on the International Space Station, Price Structure and Schedule for US Resources and Accommodations < http://commercial.hq.nasa.gov/price/structure.html $>$ (last accessed 10 September 2002).

8 Convention Establishing the World Intellectual Property Organization (14 July 1967) 828 UNTS 3, art 2(viii). 
protection for industry over its investment in the research and development of new technology. Generally the product of such investment will be "inventions", solutions to specific technical problems. ${ }^{9}$ The main intellectual property rights necessary to establish a viable commercial space program are therefore those that protect "inventions", namely patent grants. ${ }^{10}$

\section{The essential incidents of patent rights}

A patent is: 11

a document, issued, upon application, by a government office ... which describes an invention and creates a legal situation in which the patented invention can normally only be exploited (manufactured, used, sold, imported) with the authorization of the owner of the patent.

Patents have their origins in the Venetian statutes of 1474 and the English Statue of Monopolies 1628. ${ }^{12}$ Conceptualised as "a bargain between the inventor and the government", ${ }^{13}$ patents are designed to promote the development of science and useful technology by providing a proprietary incentive for inventors. ${ }^{14}$

The basic framework of patent rights is as follows. A State ("the granting State") grants to an individual ("the patent holder") a patent over a particular invention. The patent allows the patent holder to prevent another ("the user") from exploiting the invention as a matter of the domestic law of the granting State. Although a patent is sometimes expressed as a positive "monopoly" right to exploit an invention, the essential right associated with a patent is negative. That is, what is provided by the grant of a patent is the ability for the patent holder to use legal mechanisms to prevent the user from exploiting the invention that forms the "subject matter" of the patent.

Defining the exact characteristics of a patent is somewhat difficult. The exact nature of a patent right will depend on the particular domestic law of the granting State, and this may vary

9 World Intellectual Property Organisation WIPO Intellectual Property Handbook: Law, Policy and Use (WIPO Publication No 489(E), Geneva, 2001) $17<\mathrm{http} / / /$ www.wipo.org/about-ip/en/iprm/> (last accessed 7 September 2002).

10 See, for example, Marguerite Broadwell "Intellectual Property and the Economic Development of the International Space Station" (Speech to the Space Technology and Applications International Forum, Albuquerque, February 2000); Patents in Space Act (1990) 35 USC $§ 105$.

11 WIPO Intellectual Property Handbook: Law, Policy and Use, above. See also Patents Act 1953, s 2 "Patents" and "Inventions".

12 Leo Malagar and Mario Apalisok Magdoza-Malagar "International Law of Outer Space and the Protection of Intellectual Property Rights" (1999) 17 BU Int'l LJ 311, 350.

13 Christopher DeCluitt "International Patent Prosecution, Litigation and Enforcement" (1997) 5 Tulsa J of Comp and Int'l L 135, 136.

14 See, for example, H I Dutton The Patent System and Inventive Activity During the Industrial Revolution 1750-1852 (Manchester University Press, Manchester, 1984) 17-29. 
considerably in detail. However, some consistency between jurisdictions has been facilitated by a series of multilateral agreements that establish minimum international standards of patent protection, in particular the World Trade Organisation's Agreement on the Trade Related Aspects of Intellectual Property ("the TRIPs Agreement"). ${ }^{15}$

\section{The Dual Nature of Patent Rights}

Patent law is therefore sometimes said to have a dual nature, in that it is a creature of both international and domestic law. ${ }^{16}$ Domestic law, because patent rights are granted and enforced under the domestic law of individual States. International law, because multi-lateral treaties guarantee international minimum standards of patent protection for inventors.

However, despite this internationalisation of standards, patents remain essentially domestic rights. Patents are granted unilaterally by governments of individual States. Although multilateral treaties have achieved a measure of universality for domestic protection standards, the international community has yet to achieve universality of enforcement. Even those instruments that attempt to create a measure of universality, such as the Patent Co-operation Treaty 1978 and various regional attempts such as the European Patent Convention, are essentially facilitative mechanisms for making multiple domestic patent applications, rather than a true supranational patent. ${ }^{17}$

International law however has a further significant interface with patent law, in determining the limits of States' ability to enforce domestic patent legislation. The patent will only be effective in preventing the user's exploitation of the invention where the granting State has jurisdiction in international law to enforce its law against the user. The patent holder's rights are therefore, in a real sense, subject to both the domestic law of the granting state and international law.

Two forms of State jurisdiction must be distinguished here: prescriptive and enforcement jurisdiction. Prescriptive jurisdiction refers to the ability of a State to declare particular conduct subject to its laws. Enforcement jurisdiction refers to the ability of a State to enforce its law against a particular individual by taking enforcement measures such as seizure of property. The two forms of jurisdiction are distinct, and do not necessarily coexist. In order to legitimately provide effective patent rights over space-based activity, the granting State must have both.

A granting State will have both prescriptive and enforcement jurisdiction if the user's conduct occurs within the territory of the granting State. As this is by far and away the most common

15 Agreement on Trade Related Aspects of Intellectual Property Rights (Annex 1C, World Trade Organisation, Marrakesh Agreement) (1 January 1995), arts 27-35.

16 A M Balsano "Intellectual Property Rights and Space Activities" (September 1995) 15 ECSL News < http://esapub.esrin.esa.it/ecsl/ecsl15/ecsl15ba.htm> (last accessed 29 September 2002).

17 Christopher DeCluitt "International Patent Prosecution, Litigation and Enforcement" (1997) 5 Tulsa J of Comp and Int'l L 135, 144-146. 
circumstance of patent enforcement, patents are sometimes said to be territorial in nature. ${ }^{18}$ However, territorial jurisdiction is but one form of jurisdiction which a State can exercise. Patent rights may be enforceable extra-territorially so long as the granting State can exercise jurisdiction on some other basis. ${ }^{19}$

\section{B Jurisdiction in Space and the Application of Domestic Patent Legislation}

Space does not form part of the territory of any particular State. ${ }^{20}$ Article 2 of The Treaty on Principles Governing the Activities of States in the Exploration and Use of Outer Space, Including the Moon and Other Celestial Bodies 1967 ("the Principles Treaty 1967") establishes that space is res communis, a "common area", with the declaration that "Outer space, including the moon and other celestial bodies, is not subject to national appropriation by claims of sovereignty, by means of use or occupation, or by any other means". 21 The "non-appropriation" principle precludes territorial sovereignty in space and hence the exercise of territorial jurisdiction over space-based activities by a State.

Where does this leave enforcement of patents that cover space-based inventions? Generally where the subject matter of a patent involves a pure space-activity, for instance a method of using microgravity to produce special materials, infringement will only be possible by carrying out activities in space. ${ }^{22}$ In order to legitimately prohibit such activities as infringing a patent right, the granting State must have some form of extra-territorial prescriptive jurisdiction over the activities. ${ }^{23}$

18 DeCluitt, above, 137.

19 This is the position as a matter of international law. If the domestic patent law of the granting State is expressly territorial, extra-territorial jurisdiction may be excluded. This is the case with patent law of the United States of America.

20 Although a State's territory includes the airspace above its land territory, it does not extend further upwards into the outer atmosphere and beyond: Convention on International Civil Aviation (7 December 1944) 15 UNTS 295, art 1. While the precise boundary between a State's territorial airspace and space is uncertain, it is accepted that most, if not all, satellite orbits exist above the territorial airspace: Leo Malagar and Mario Magdoza-Malagar "International Law of Outer Space and the Protection of Intellectual Property Rights" (1999) 17 BU Int'l LJ 315, 317; D J Harris Cases and Materials on International Law (5 ed, Sweet \& Maxwell, London, 1998) 253; Fred Kosmo "The Commercialisation of Space: A Regulatory Scheme that Promotes Commercial Ventures and International Responsibility" (1988) 61 S Cal L Rev 1055, 1061-1062.

21 Treaty on Principles Governing the Activities of States in the Exploration and Use of Outer Space, Including the Moon and Other Celestial Bodies (27 January 1967) 15 UNTS 206. A fuller discussion of the status of space as a "common area" is contained in the original version of this paper: Timothy Smith $A$ Phantom Menace? Patents and the Communal Nature of Space (LLM Paper, Victoria University of Wellington, 2002, deposited in the VUW Law Library).

22 See, for example, Ex Parte McKay (1975) 200 USPQ 324 (PTO BA).

23 It may be that in some cases territorial jurisdiction can be asserted over infringements of patents that are essentially concerned with space activities. In Hughes $v$ United States of America, the Federal Court of Claims held that the launch of a spacecraft in the United States constituted use of a patent over that 
In the absence of territorial jurisdiction the Principles Treaty 1967 establishes, or rather transfers, the concept of "flag-state" jurisdiction to space. ${ }^{24}$ "Flag-State" jurisdiction allows States to assert extra-territorial jurisdiction over conduct in areas not subject to territorial appropriation by allowing the state of nationality of a vessel on which the conduct occurs (the "flag State") to exercise exclusive jurisdiction over the vessel when it is in the common area. The concept of flagState jurisdiction was developed in relation to the res communis area of the high seas, ${ }^{25}$ and is considered to form an essential part of the "freedom of the high seas". ${ }^{26}$ The nationality of the ship "provides a necessary criterion ... in locations ... where the 'territorial' criterion is inappropriate."27

Nationality of a vessel, or "space object" in the language of the United Nations' space treaties, is determined by registration, in a further analogy with the law of the sea. Compulsory registration of space objects is facilitated by the Registration Convention, which requires that either the State that launches a space object or procures the launching of a space object must register the object on its national register. ${ }^{28}$ States "on whose registry an object launched into outer space is carried shall retain jurisdiction and control over such object, and over any personnel thereof" ${ }^{29}$

It is this "registry" jurisdiction under which the current grant of patents over space-based inventions is legitimised. The leading decision establishing this "conventional thesis" is Ex Parte McKay. ${ }^{30}$ In that case, the Appeals Board of the United States Patent and Trademark Office Board of Appeals was concerned with an earlier rejection of a patent application for a process of obtaining

spacecraft's guidance system, even though that system could only be used in space: Hughes $v$ United States of America (1993) 29 Fed Cl 197, 226. However, the Hughes cases seems a special case. The court relied, inter alia, on the particular wording of the patent grant, which included the whole body of the spacecraft, not just the elements of the guidance system, as the subject matter of the patent. Thus, the issue of use concerned any use of the entire spacecraft.

24 Treaty on Principles Governing the Activities of States in the Exploration and Use of Outer Space, Including the Moon and Other Celestial Bodies (27 January 1967) 15 UNTS 206, art 8.

25 United Nations Convention of the Law of the Sea (1982) 21 ILM 1261, art 92(1)

26 Sellers v Maritime Safety Inspector [1999] 2 NZLR 45, 47 (CA) Keith J.

27 Ian Brownlie Principles of Public International Law (5 ed, Oxford University Press, Oxford, 1998) 306.

28 Convention on Registration of Objects Launched into Outer Space (14 January 1975) 28 UST 695, arts 1(a), 2(1) and 2(2).

29 Treaty on Principles Governing the Activities of States in the Exploration and Use of Outer Space, Including the Moon and Other Celestial Bodies (27 January 1967) 15 UNTS 206, art 8.

30 The jurisprudence from the United States is, however, complicated by the provisions of the United States' Federal Code which provide that United States' patent laws have no extra-territorial effect: Deepsouth Packing Co v Laitram Corp (1972) 406 US 518, 531. This has led courts to speak of "quasi-territorial jurisdiction" over space objects rather than "flag-based jurisidiction" which is based on the nationality of the craft. 
oxygen from extra-terrestrial materials. ${ }^{31}$ The respondent sought to uphold the rejection on the grounds that, inter alia, United States' patent law could not apply to inventions that could only be exploited in space.

The Appeals Board rejected this argument and would have granted that patent had it possessed the requisite novelty. ${ }^{32}$ The Appeals Board considered that the crucial dichotomy lay between the prohibition on appropriation in article 2 of the Principles Treaty and the exercise of jurisdiction. However, relying on article 8 of the Treaty, the Appeals Board held that: ${ }^{33}$

It is clear from Article VIII of said Treaty that jurisdiction of the United States in personam over any person is present if the object launched into outer space is of United States registry ... A patent grant under 35 USC 154 by the United States for a process to be carried out on the moon by personnel subject to its jurisdiction is thus not inimical and at variance with [United States' patent law].

This decision establishes that private intellectual property rights in space granted unilaterally by individual States are legitimate because the jurisdiction required to make such rights effective is provided by the nationality based registry jurisdiction over space objects.

An important gloss on the conventional thesis should be noted. The Principles Treaty and Registration Convention do not explicitly differentiate between prescriptive and enforcement jurisdiction, both referring only to "jurisdiction" in general. Nor is it apparent whether registry jurisdiction is exclusive, in the sense that it excludes the exercise of concurrent jurisdiction by other States. If the analogy with the law of the sea is extended, it is arguable that registry jurisdiction refers to exclusive enforcement jurisdiction only. Thus in respect of vessels on the high seas, while a State has the exclusive ability to take enforcement measures on board or against vessels, it does not have exclusive prescriptive jurisdiction. ${ }^{34}$ Another State may prescribe an individual's conduct as illegal on foreign national vessels, although it may not enforce them until the individual comes within its enforcement jurisdiction. ${ }^{35}$

The potential implications for this on the application of domestic patent law is significant. As enforcement measures will rarely, if ever, be actually taken on space objects in orbit, if prescriptive jurisdiction can be asserted without reference to the nationality of the space object but on some other extra-territorial ground, the scope for interference with space use, particularly by launching States, with activities on other States' space objects is significant.

31 Ex Parte McKay (1975) 200 USPQ (BNA) 324 (PTO BA)

32 Ex Parte McKay, above, 327.

33 Ex Parte McKay, above, 326.

34 Sir Robert Jennings QC and Sir Arthur Watts QC (eds) Oppenheim's International Law (9 ed, Longman Group, Harlow (Essex), 1992) 463.

35 Sellers v Maritime Safety Inspector [1999] 2 NZLR 45, 49 per Keith J; $R v$ Kelly [1982] AC 665 (HL). 
Perhaps for this reason, it appears to have been accepted by the international community that the jurisdiction referred to by the Principles Treaty, at least in respect of civil jurisdiction required to enforce patent rights, is both exclusive prescriptive and exclusive enforcement jurisdiction. Therefore, only the registry State can assert that its domestic patent laws apply to activities occurring on a space object. Thus, in Hughes $v$ United States of America, NASA argued that the United States' Courts did not have jurisdiction to consider patent infringement claims on board nonUnited States' registered craft. ${ }^{36}$ The Court of Federal Claims did not find it necessary to determine the position at international law, holding that Congress had not intended its legislation to so apply.

Further evidence for this position is provided by the Inter-Governmental Agreement governing the construction and use of the International Space Station. ${ }^{37}$ The International Space Station has been constructed around a modular design, with each of the States parties to the Agreement responsible for the delivery of certain elements into orbit which are then joined together to form the space station. Each State must register the elements that it provides under the Registration Convention. ${ }^{38}$ Consistent with the argument that only the registry State may assert prescriptive jurisdiction, the Agreement then goes on to deem that: ${ }^{39}$

for purposes of intellectual property law, an activity occurring in or on a Space Station flight element

shall be deemed to have occurred only in the territory of the Partner State of that element's registry.

The conventional thesis can be summarised as follows. Space is res communis, and cannot therefore be subject to national appropriation. No appropriation of any area is necessary by an granting State to enforce patent rights in favour of an individual. Rather, what is required is the ability to control conduct of individuals; this can be facilitated through the exercise of jurisdiction over the space object on which their activities are based. Article 8 of the Principles Treaty allows the State of registry of a space object to assert prescriptive jurisdiction over that object. Thus, the application of domestic patent laws by a granting State over space activities carried out on a space object registered on its registry is a legitimate exercise of sovereignty under international law.

The remainder of this paper explains why the above is a misrepresentation of the actual effect of unilateral patent grants on the status of space as an international common area.

36 Hughes $v$ United States of America (1993) $29 \mathrm{Fed} \mathrm{Cl} \mathrm{197,} 229$

37 Agreement Among the Government of Canada, the Governments of Member States of the European Space Agency, the Government of Japan, the Government of the Russian Federation, and the Government of the United States Concerning Co-operation on the Civil International Space Station (29 January 1998) <ftp://ftp.hq.nasa.gov/pub/pao/reports/1998/IGA.html> (last accessed 14 September 2002) ["InterGovernmental Agreement"].

38 Inter-Governmental Agreement, above, art 5(2).

39 Inter-Governmental Agreement, above, art 21(2). 


\section{A THEORETICAL CONFLICT: PATENT RIGHTS AND FREEDOM OF USE}

\section{A Freedom of Use of Space}

Res communis describes a state of communal ownership over a particular resource, outside the ownership of a particular individual. ${ }^{40}$ In the case of the high seas, and space the resource is the area itself. While the term does "not provide a viable regime" for management of the area itself, it does provide a fundamental paradigm for use. ${ }^{41}$ The description of an area as res communis: ${ }^{42}$

indicates equal and free common access - the commonness of a common well, for example, from which all may draw their water, or of a common pasture, where all their livestock may graze.

The principle of res communis has two fundamental aspects. The first is that the area cannot be appropriated into the territory of any State. The second, and equally fundamental rule, is that all States have the right to use the area; States are "bound to refrain from any acts which might adversely affect the use of the [common area]". 43

The Principles Treaty 1967 reflects this "freedom of use" aspect of res communis. Article 1 of the Principles Treaty 1967 states that:

The exploration and use of outer space, including the moon and other celestial bodies, shall be carried out for the benefit and in the interests of all countries, irrespective of their degree of economic or scientific development, and shall be the province of all mankind.

Outer space, including the moon and other celestial bodies, shall be free for exploration and use by all States without discrimination of any kind, on a basis of equality and in accordance with international law, and there shall be free access to all areas of celestial bodies.

There shall be freedom of scientific investigation in outer space, including the moon and other celestial bodies, and States shall facilitate and encourage international co-operation in such investigation.

Unlike the non-appropriation aspect of res communis, the obligation on States not to interfere with the free use of the communal space resource does not directly affect the assertion of a particular basis of jurisdiction over space-based activities. Rather what is required is that the assertion of jurisdiction does not interfere with the "free use" of space; this will depend on the effect of the substantive law being asserted. The next part of this paper suggests that there is a fundamental conflict between patent rights and the "free use" of space.

40 J E S Fawcett Outer Space: New Challenges to Law and Policy (Clarendon Press, Oxford, 1984) 5.

41 Ian Brownlie Principles of Public International Law (5 ed, Oxford University Press, Oxford, 1998) 174.

42 L F E Goldie "Title and Use (and Usufruct) - An Ancient Distinction Too Oft Forgot" (1985) 79 AJIL 689, 698.

43 Brownlie, above, 175. 


\section{B Patent Rights and Freedom of Use}

In essence, a patent gives the right to an individual to exclude others from carrying out a particular activity. Where that activity relates to the use of a common area, patents give a monopoly right to an individual over that use. As such, they arguably conflict with the "freedom of use" principle implicit in the status of space as res communis and as provided for in the United Nations' space treaties.

Patents may here be contrasted with tangible personal property in their restriction of use. It has been argued by some commentators that patent rights can be conceptualised as analogous to tangible property launched into space. ${ }^{44}$ The Principles Treaty implements a regime in which "outer space is freely available for use by all, but that personal rights in tangible property may be protected". 45 Thus, a private individual retains ownership of the satellite which is placed into orbit. Some commentators from this "take another inferential step and reason that intangible property rights must be protected as well". 46

Such an analysis fails to distinguish between use of objects in exploiting an area that is res communis and uses of an area that is res communis. Personal property rights in satellites are defined, inter alia, by the ability to exclude others from the use of the object in which the personal property rights are held. This exclusion, may of course, have the effect of restricting another's activities in space; one may not be able to use another's satellite to send one's communications, for example. However, this restriction does not directly interfere with one's uses of space. One is still free to use space to send communications.

The distinction between uses of a res communis area and uses in a res communis area can be understood in terms of the analogy of a common well, from which all may draw water. If a villager, A, has personal property in a bucket and consequently the ability to withhold that bucket from another villager, B, then A's personal property rights adversely affect the ability of B to use the common resource. However, this is a secondary effect of the personal property right. What in fact the personal property right prevents is use of A's bucket in exploiting the common well. B is still free to draw water from the well using other means, including his or her own bucket; as such his or her right to use the well is undiminished. The communal nature of the well remains. Conversely, if A has a personal property right that enables A to exclude B from using the well to draw water from, $\mathrm{B}$ 's right to use the well is diminished. The property right is concerned directly with the use of the

44 Dan Burk "Application of United States Patent Law to Commercial Activity in Outer Space" (1991) 6 Santa Clara Computer \& High Tech LJ 295, 314.

45 Burk, above, 314.

46 Ty S Twibell "Space Law:Legal Restraints on Commercialisation and Development of Outer Space" (1997) 65 UMKC LR 590, 617. See also, Burk, above. 
common resource. B may still use the well for other uses, but not for drawing water. The communal nature of the well is reduced.

It appears strongly arguable that certain patents involve the grant of a personal property right in the use of space. Consider a patent for "a method for producing magnetostrictive material", a particular type of "smart material". 47 Intrinsic to the process over which the patent is granted is cooling the material in a micro-gravity environment. As such, the process patented makes use of the of the space environment itself. The patent right therefore excludes others from, inter alia, making use of space in that particular manner. Similarly, a patent over a method of "obtaining oxygen from extraterrestrial material" as in Ex parte McKay would prevent others from making a particular use of space materials. 48

Unlike a common well, where basically the sole use that may be made of the resource is the drawing of water, there are an almost infinite number of further uses of space that flow from the unique intrinsic properties of the space environment. It is those intrinsic properties that the research conducted on the International Space Station will exploit. For example, two properties of the space environment, microgravity and ultra-vacuum, afford unique opportunities for materials processing. ${ }^{49}$ Use of these properties of the space environment constitutes a use of the res communis resource of space as much as placing a satellite in orbit.

It seems likely that the majority of technology invented in space will fall within this category where the subject matter of the patent involves a use of the intrinsic properties of space. The expense of space research means that research that could be conducted on Earth using cheaper facilities would be. Any research in space is therefore likely to involve use of the intrinsic features of the space environment that cannot be recreated cost-effectively on earth, such as micro-gravity and ultra-vacuum. Thus, the inventions that are the product of this research will inevitably involve the use of those features.

However, not all patents relating to space-based activities will make use of space. This will include many product patents over inventions that, while allowing use of space, do not make use of space and are not manufactured in space. An example of such a patent is a "device for manual electron beam processing of materials in space". ${ }^{50}$ The patent discloses a device which is essentially a oxy-acetylene torch for space use. The apparatus does not have to be manufactured in space, and does not rely on the intrinsic properties of space to operate, although its usefulness is

47 "A Method of Preparting a Magnetostrictive Material" (13 March 2003) EP Patent No 1186364.

Ex parte McKay (1975) 200 USPQ 324 (PTO AB).

49 Andrew Young Law and Policy in the Space Stations' Era (Kluwer Academic Publishers, Netherlands, 1989) 136.

50 "Device for Manual Electron Beam Processing of Materials in Space" (9 February 1999) US Patent No $5,869,801$. 
limited to space. In this sense, the subject matter of the patent is not a use of space. This interference with free use of space cause by such patents is far more analogous to the interference with use caused by tangible personal property rights. Thus, while the patent has the secondary effect of restricting the use of space, in that it restricts the availability of tools necessary to use space in a particular way, it does directly affect the free use of space. The patent is a bucket, rather than a use right.

\section{LEGAL CONSEQUENCES OF THE THEORETICAL CONFLICT}

It does not necessarily follow from the above discussion that the application of patent laws to space-based activities is contrary to international law. Instead, the immediate implication to be drawn from the theoretical conflict is that the conventional thesis "hides something" from the casual viewer; the interface between the international law of outer space and patent rights is more complex and sophisticated than merely being able to point to a basis of exercising jurisdiction over individuals in space.

Rather, a complete thesis of the interface between the international law of space and patents must explain how the potential theoretical conflict between rights of free use and the unilateral application of domestic patent law is "diffused". Put another way, what is it about the nature of the rights of freedom of use implicit in res communis and found in the United Nations' space treaties that means that patent rights to methods of space utilisation do not interfere with them?

\section{A The Proper Interpretation}

Before launching into an analysis of the treaty provisions, it should be noted that we are here seeking an explanation of an outcome, that the application of domestic patent law to space-based activities is legitimate, rather than investigating whether the theoretical conflict has legal consequences. That the theoretical conflict must be resolved in favour of legitimacy might seem like placing the cart before the horse, were it not for the fact that 30 years of State practice indicates that the unilateral grant of patents over space based activities is accepted. While the theoretical conflict has been stated and argued in the abstract, it would be erroneous to similarly treat the interface between international law and the unilateral application of domestic patent law to space-based activities.

International customary law is a creature of State practice. As such, it can be altered by State practice, coupled with the requisite opinio juris, that deviates from the norm. Similarly, while provisions in treaties are immutable, the meaning given to the particular provisions is less so. Article 31(3)(b) of the Vienna Convention on the Law of Treaties 1969, regarded as stating customary international law, ${ }^{51}$ establishes that treaties must be interpreted taking into account, inter

51 Qatar v Bahrain (Maritime Delimitation and Territorial Questions [1995] ICJ Rep 6, 18. 
alia, "any subsequent practice in the application of the treaty which establishes the agreement of the parties regarding its interpretation".

Therefore, while the provisions of the United Nations' space treaties are the starting point of any analysis of the international law of space, this cannot be to the exclusion of subsequent State practice. Moreover, if the State practice that surrounded the acceptance of the treaties was essentially exploratory, the first space stations capable of exploitation of space not appearing until the $1970 \mathrm{~s},{ }^{52}$ this cannot exclude from relevance the subsequent 30 years of exploitative space utilisation. Nor can it exclude from relevance the extensive history of assertions of patent jurisdiction by space-faring States and the apparent acceptance, at an international level, of the legitimacy of the application of domestic patent laws over space based activities.

The development of the latter can be seen in the use of intellectual property provisions in the cooperation agreements between space-faring States. The 1990 Agreement between the European Space Agency and the Government of the USSR Concerning Co-operation in the Field of the Exploration and Outer Space for Peaceful Purposes is one of the first such agreements. The Agreement in the main envisages the open disclosure of information and data obtained in joint projects "free of charge", 53 a characteristic of the exploratory paradigm. However, it also requires Implementing Arrangements to be established to deal with, inter alia, the acquisition and use of intellectual property rights over inventions, data and assets. ${ }^{54}$

Conversely, the Agreement Between the United States of America and the Russian Federation Concerning Cooperation in the Exploration and Use of Outer Space for Peaceful Purposes 1992 does not deal with open access to information. ${ }^{55}$ Instead of open exchange of information and data, "the Parties shall ensure adequate and effective protection of intellectual property created or furnished under this Agreement". ${ }^{56}$ Indeed the main text of the Agreement itself is only slightly

52 LB Taylor Jr For All Mankind: America's Space Programs of the 1970s and Beyond (EP Dutton \& Co, New York, 1974) 5.

53 The Agreement between the European Space Agency and the Government of the USSR Concerning Cooperation in the Field of the Exploration and Outer Space for Peaceful Purposes (18 May 1990) ESA Doc ESA.LED 123, art 8. See Karl-Heinz Böckstiegel and Mariètta Benkö Space Law: Basic Legal Documents (Martinus Nijhoff, Dordrecht (The Netherlands), 1993) vol 2/1 D (last updated 1 November 1999).

54 The Agreement between the European Space Agency and the Government of the USSR Concerning Cooperation in the Field of the Exploration and Outer Space for Peaceful Purposes, above, art 6.

55 Agreement Between the United States of America and the Russian Federation Concerning Cooperation in the Exploration and Use of Outer Space for Peaceful Purposes 1992 (17 June 1992). See Böckstiegel and Benkö, above.

56 Agreement Between the United States of America and the Russian Federation Concerning Cooperation in the Exploration and Use of Outer Space for Peaceful Purposes, above, art 6. 
longer than the sole Annex to the Agreement, which sets out, in detail, the division of intellectual property rights to each Party and mechanisms for dispute resolution.

The Inter-Governmental Agreement governing the construction and use of the International Space Station similarly makes no provision for the free flow of information other than the technical data required to construct the station and, even then, tight restrictions are placed on the transfer. ${ }^{57}$ As for knowledge and information generated by research on the International Space Station, article 21 confirms the right of the registry State to apply its intellectual property laws to activities on the elements.

The apparent acquiescence of the international community to the unilateral application of domestic patent laws over space-based activities means that it is impossible to argue that the grant of patents over uses of space is contrary to customary international law or the provisions of the United Nations' space treaties. Nonetheless, it is useful to examine how this consistency between international law and the unilateral grant of patent rights is achieved.

\section{B Interpretation of the "Freedom of Use" Provisions in the United Nations' Space Treaties}

The Principles Treaty 1967 contains both rights and obligations for signatory States. Article 1 of the Principles Treaty states the rights of States to free use. The subsequent provisions of the Treaty State obligations, both positive and negative, in the exercise of that freedom of use. However, aside from article 2 which contains the non-appropriation principle, the freedoms secured in article 1 are, with one exception, ${ }^{58}$ not directly reinforced by subsequent explicit obligations on States. The crucial obligation upon States flowing from the rights of free use guaranteed in article 1 is therefore simply to refrain from conduct that adversely affects the use of space by others in accordance with the guaranteed freedoms. ${ }^{59}$

57 Agreement Among the Government of Canada, the Governments of Member States of the European Space Agency, the Government of Japan, the Government of the Russian Federation, and the Government of the United States Concerning Co-operation on the Civil International Space Station (29 January 1998) <ftp://ftp.hq.nasa.gov/pub/pao/reports/1998/IGA.html> ["Inter-Governmental Agreement"] arts 19-20.

58 Article 11 of the Principles Treaty 1967 promotes freedom of scientific investigation by providing for a free flow of information concerning scientific investigation. Patent rights are not inconsistent with a requirement for disclosure of scientific material as patent rights do not restrict flow of information, but rather the use of that information. For a fuller discussion of this point, see the earlier version of this paper: Timothy Smith A Phantom Menace? Patents and the Communal Status of Space (LLB(Hons) paper, Victoria University of Wellington, 2002, deposited in the VUW Law Library).

59 Ian Brownlie Principles of Public International Law (5 ed, Oxford University Press, Oxford, 1998) 174175 . 
Article 1 of the Principles Treaty 1967 contains three provisions that concern free use of the common area of space. ${ }^{60}$ The first paragraph declares the exploration and use of space to be "the province of all mankind". The second paragraph declares that space shall be free for "exploration and use" by all States. The third paragraph concerns a more specific freedom, the "freedom of scientific investigation". Nonetheless, the freedoms guaranteed by article 1 are not mutually exclusive and do not form three distinct rights requiring independent analysis.

The concept of the "province of mankind" in article 1 of the Principles Treaty is used as a unifying concept, incorporating the idea of freedom of use in article 1(2) and the non-appropriation principle in article 2.61 The province of mankind is best understood, therefore, as a "sort of a freedom-of-the-seas provision". 62 The concept is therefore somewhat broader than simply a guarantee of freedom of use. As such, it is probably better to deal with the right of free use under the specific provision in article 1(2), although the unifying concept of the province of mankind may provide an insight into its interpretation. Conversely, the scientific investigation, the freedom of which is guaranteed by article 1(3), almost certainly falls within the definitions of "exploration" and use" in article 1(2). The crucial article as regards the right of free use of space is therefore article $1(2)$.

Article 1(2) both provides for freedom of "exploration" and "use". "Exploration" and "use" represent the twin aspects of space utilisation envisaged by the international community. "Exploration" refers to scientific exploration of the space environment. Conversely, "use" is the equivalent of "exploitation". ${ }^{63}$ The inclusion of "use" in article 1 thus indicates international acceptance "of peaceful activities in outer space other than scientific exploration only"64 and indeed guarantees the freedom to conduct such activities.

The activities considered by the international community to fall within "use" is instructive. The travaux préparatoires of the Principles Treaty indicate that the delegates considered "use" to include, inter alia, "meteorological research, telecommunications and extraction of Moon minerals."65 The inclusion of meteorological research and telecommunications in this list is significant, because it indicates that "use" is not limited to extractive utilisation, in the sense of

60 Treaty on Principles Governing the Activities of States in the Exploration and Use of Outer Space, Including the Moon and Other Celestial Bodies (27 January 1967) 15 UNTS 206, art 1.

61 Carl Q Christol Space Law: Past, Present and Future (Kluwer Law \& Technology Publishers, Deventer (The Netherlands), 1991) 71

62 Ambassador Goldberg quoted in Christol, above, 71.

63 See, for a discussion of the travaux préparatoires to the Principles Treaty 1967, Christol, above, 68.

64 Press Release USUN-18 (7 April 1977) [1979] Digest of US Practice in Int'l Law 661.

65 Christol, above, 68. 
mining minerals, but also includes non-extractive utilisation of the intrinsic properties of the space environment itself.

The freedom of "use" also extends to commercial activities. The Principles Treaty is silent on commercial usage, however subsequent State practice by space-faring nations suggests that commercial use of orbit is accepted as legitimate by the international community. ${ }^{66}$ Commercial freedom is not impeded by the requirement in article 1(1) of the Principles Treaty that space activities be carried out "for the benefit and in the interests of all countries." Article 1(1) has been "read down" by the international community as not importing specific obligations on States, ${ }^{67}$ or at least not requiring that the benefits of use be shared in the specific sense, but rather that the activity contribute to the general good in a broad sense. ${ }^{68}$

As such, the right to free use of space would seem to extend to commercial exploitation of the intrinsic properties of space. The important issue, therefore, in realising the legitimacy of unilateral patent grants over uses of space is to whom those rights extend. Patents are, by virtue of the conventional thesis, limited in effectiveness to the registry jurisdiction of the granting State. The limits on the free use of space implicit in certain patents are restricted to activities on board space objects registered on the registry of the granting State. As such, there are three categories of entities whose free use of space can thus be restricted. First, the granting State itself. This restriction is best seen as self-imposed and does not require further discussion. Second, individual users of the space object. Third, agents of other States. The crux of the issue is whether restrictions on the activities of individuals and other States violate the provisions guaranteeing freedom of use. Put another way, what rights do individuals and non-registry States possess under article 1 of the Principles Treaty?

\section{Individuals}

The Principles Treaty certainly does not exclude the possibility of private individuals utilising space. ${ }^{69}$ Originally, this was the intention of the USSR, which proposed that "all activities ... shall

66 Fred Kosmo "The Commercialization of Space: A Regulatory Scheme that Promotes Commercial Ventures and International Responsibility" (1988) 61 S Cal L Rev 1055, 1067.

67 Christol, above, 71 .

68 K Tatsuzawa "The Regulation of Commercial Space Activities by the Non-Governmental Entities in Space Law" (1988) IISL-88-083 <http://www.spacefuture.com/archive/the_regulation_of_commercial_space _activities_by_the_non_governmental_entities_in_space_law.shtml> (last accessed 22 September 2002).

69 See Treaty on Principles Governing the Activities of States in the Exploration and Use of Outer Space, Including the Moon and Other Celestial Bodies (27 January 1967) 15 UNTS 206, art 6; Karl Heinz Böckstiegel "Legal Aspects of Space Activities by Private Enterprises" in Schwartz (ed) Proceedings of the $19^{\text {th }}$ Colloquium on the Law of Outer Space (International Institute of Space Law of the International Astronautical Federation, 12-15 October 1976, Anaheim (California)) 234, 234. 
be carried out solely or exclusively by [S]tates". ${ }^{70}$ However, the United States objected to this proposal, ostensibly because to restrict use to States would be inconsistent with space as the province of mankind. The final language of the treaty is largely silent on the issue, although certain provisions indicate the possibility of space activities by non-State entities. Thus, for example, States are responsible for the national activities in space, whether carried on by the State itself or by "nongovernmental entities". ${ }^{71}$

However, if private individuals are free to utilise space, it does not necessarily follow that the freedom to use space is guaranteed. Article 1 provides that space shall be "free for exploration and use by all States", not all individuals. However, despite this provision: ${ }^{72}$

It is now considered to be the right of natural and juridical persons other than States, as well as States, to have the right of free and equal access to the space environment per se. Moreover, the rights of such persons are extended to exploration, exploitation and use. They may also engage, pursuant to Article 1, in scientific investigations.

However, it seems equally clear that the freedom of use for individuals is not without limits. This is apparent from the wording of the United States of America's rejection of the Soviet proposal that only States should be able to use space. The American position was premised on the ideal that: ${ }^{73}$

Man should be free to venture into space on the same basis that he has ventured on the high seas - free from any restraints save those imposed by the laws of his own nation and by the rules of international law, including those embodied in the United Nations charter.

A small correction is necessary to this statement of principle. Humankind does not venture onto the high seas free from any restraints save those imposed by the laws of his or her own nation, but rather free from restraints save those imposed by the law of his or her vessel's nation. ${ }^{74}$ It is highly probable, therefore, that by analogy, as argued for by the United States, it is also this principle that governs individual use of space. Indeed the existence of such restraints forms the basis of the

70 Böckstiegel, above, 234 citing a Soviet draft of the Principles Treaty (10 September 1962) UN Doc A/AC195/L2.

71 Treaty on Principles Governing the Activities of States in the Exploration and Use of Outer Space, Including the Moon and Other Celestial Bodies (27 January 1967) 15 UNTS 206, art 6.

72 Carl Cristol "Article 2 of the 1967 Principles Treaty Revisited" in Glenn Reynolds and Robert Merges (eds) Outer Space: Problems of Law and Policy (Westview Press, Boulder, 1989) 78, 80.

73 The statement of Ambassador Stevenson in the Committee (Political and Security) of the General Assembly on 4 December 1961, cited in K Tatsuzawa "The Regulation of Commercial Space Activities by the NonGovernmental Entities in Space Law" (1988) IISL-88-083 <http://www.spacefuture.com/ archive/the_regulation_of_commercial_space_activities_by_the_non_governmental_entities_in_space_law. shtml $>$ (last accessed 29 September 2002)

74 H Lauterpacht (ed) Oppenheim's International Law (8 ed, Longmans, London, 1955) 618-619. 
ultimate Soviet withdrawal of their demands that space be the province of States only. The Soviet position was that: ${ }^{75}$

it would be possible to consider the question of not excluding from the declaration the possibility of activity in outer space by private companies, on the condition that such activity would be subject to the control of the appropriate State, and the State would bear international responsibility for it.

The "appropriate State" as realised by the Principles Treaty 1967 and the subsequent United Nations' space treaties is the registry State of the space object. ${ }^{76}$

It is this interpretation of the rights of individuals that is necessary to legitimise the application of domestic patent laws to space-based activities in respect of the obligation not to interfere with the free use of space by others. It is worth emphasising that restricting interference with individual use of space to the State of nationality of the individual would not have the same effect. Nor would simple reliance on the procedural incapacity of individuals.

Nationals must in general rely on their State of nationality to protect their rights in customary international law and in treaties to which the State of nationality is a party. ${ }^{77}$ This consequence of the lack of inherent legal personality for individuals has a further, "more ominous" consequence. It places the individual "within the domestic jurisdiction, and hence the discretionary treatment, of [the] national $[S]$ tate". ${ }^{78}$ Other states, therefore, cannot exercise diplomatic protection on that individual's behalf. ${ }^{79}$

However, two exceptions exist to the general principle that individuals must rely on their national State to protect their rights in international law. Individuals may gain limited personality if States consent to it. This development is relatively recent, and almost entirely confined to the area of international human rights. ${ }^{80}$ More importantly, individuals' rights may also gain wider protection if the norm in which the right is based is of such importance to the international

75 (1966) UN Doc A/AC 105/PV 22.

76 Treaty on Principles Governing the Activities of States in the Exploration and Use of Outer Space, Including the Moon and Other Celestial Bodies (27 January 1967) 15 UNTS 206, arts 6-8.

77 In enforcing an individual's "rights", however "a State is in reality asserting its own right, the right to ensure in the person of its nationals respect for the rules of international law". D J Harris Cases and Materials on International Law (5 ed, Sweet \& Maxwell, London, 1998) 140; Estonia v Lithuania (Panevezys-Saldutiskis Case) (1939) PCIJ Reports A/B no 76.

78 Harris, above, 142.

79 Belgium v Spain (Barcelona Traction, Light and Power Co Case) [1970] ICJ Rep 3, para 35.

$80 \mathrm{H}$ Lauterpacht "Survey of International Law in Relation to the Work of Codification of the International Law Commission) in Harris, above, 140. 
community as a whole that all States have a duty to protect against its breach. Such obligations are denoted as obligations erga omnes.

It is strongly arguable that the res communis status of space, and the principle of freedom of use implicit therein, is such an obligation. The International Court of Justice indicated in Barcelona Traction, Light and Power Co Case that the crucial indicia of obligations erga omnes is that they are "by their very nature ... the concern of all States." 81 As res communis describes a state of communal ownership, all States have an interest in preventing conduct that damages the communal nature of the area. Therefore, if the freedom of use is not itself inherently limited, other States might exercise diplomatic protection over an individual where their use was interfered with by their State of nationality.

Moreover, even if the individual right of freedom of use was inherently restricted by allowing interference with the individuals' rights by their State of nationality, it could not legitimise patents granted under the conventional thesis. For, as noted above, a patent right may interfere with the use of not only nationals of the granting State but also non-nationals on board a space object registered with the granting State. Presumably, the State of nationality of the individual affected could exercise diplomatic protection in such circumstances.

The crucial step, therefore, in accepting the legitimacy of patents over space-based activity is recognising that the registry State not only has exclusive prescriptive jurisdiction over space objects, but also has the ability to interfere with individuals' free use of space on the space object. As the example with nationality based incursions on the freedom of use discussed above shows, what is important is that the ability to assert jurisdiction goes hand in hand with the ability to restrict freedoms. Legitimacy in application of domestic patent law thus relies on more than simply being able to assert jurisdiction on a non-territorial basis, but also in the restricted nature of the rights of freedom of use that individuals possess at international law.

\section{Other States}

While the above analysis resolves any potential legal conflict between the rights of individuals to use space freely and the ability of granting States to enforce patent rights over space based activities, a further step must be taken with respect to non-registry State rights of use on other States' space objects. The inclusion of this group is not unrealistic. On the International Space Station for instance, the United States has utilisation rights to research capacity on the European and Japanese registered research modules. ${ }^{82}$

81 Belgium v Spain (Barcelona Traction, Light and Power Co Case) above, para 33.

82 National Aeronautics Space Agency International Space Station User's Guide (2 ed) 17 $<$ http://spaceflight.nasa.gov/station/reference/issug/ISSUG12-34.pdf> (last accessed 4 August 2002). 
While individuals' rights of use are subject to the law of the registry State, it is not clear that a States' right of use is subject to the same as a matter of international law. However, it seems likely that as a matter of comity, States submit to recognise the law of the registry State. While this may appear be a legal blurring, it is similar to the comity analysis that allows a "first come, first served" basis for allocating use of limited satellite orbit resources; the second State must respect the route taken by the first. ${ }^{83}$

\section{PRACTICAL CONSEQUENCES OF THE THEORETICAL CONFLICT}

Even if the unilateral grant of patents over space-based activities does not conflict with international law, there are nonetheless still practical consequences for the theoretical conflict between freedom of use and patent monopolies. Indeed it is strongly arguable that, despite the apparent legitimacy of individual State actions in applying domestic patent laws to activities in outer space, the international trend of making unilateral grants of patent rights over space-based activities nonetheless undermines the status of space as a common area. This practical effect results from the combination of the theoretical conflict with the international "nature" of patents.

As has been noted previously in this paper, patents are not supranational rights. However, the effect of international agreements such as the Agreement on Trade Related Aspects of Intellectual Property (TRIPs) is that States must provide certain minimum standards of intellectual property protection. ${ }^{84}$ The next section of the paper will focus on the effect of the TRIPs Agreement, as it contains patent specific provisions and is widely ratified. The World Trade Organisation, which requires members to ratify the TRIPs Agreement, has 144 members. ${ }^{85}$ In comparison, as of 1 February 2001, the Principles Treaty 1967 had 96 ratifications. ${ }^{86}$ The TRIPs Agreement therefore forms an important component of the international law of intellectual property.

Article 27(1) of TRIPs requires that "patents shall be available for any inventions, whether products or processes, in all fields of technology, provided that they are new, involve an inventive step and are capable of industrial application". Patent rights must be available without discrimination as to, inter alia, "the field of technology". ${ }^{87}$ Until now, patents have been

83 Fred Kosmo "The Commercialisation of Space: A Regulatory Scheme that Promotes Commercial Ventures and International Responsibility" (1988) 61 S Cal L Rev 1055, 1062.

84 Agreement on Trade Related Aspects of Intellectual Property Rights (Annex 1C, World Trade Organisation, Marrakesh Agreement) (1 January 1995).

85 Trading into the Future: The Organisation: Members and Observers <http://www.wto.org/english/thewto_e/whatis_e/tif_e/org6_e.htm> (last accessed 25 September 2002).

86 Office of Outer Space Affairs <http://www.oosa.unvienna.org/SpaceLaw/treaties.html $>$ (last accessed 25 September 2002).

87 Agreement on Trade Related Aspects of Intellectual Property Rights (Annex 1C, World Trade Organisation, Marrakesh Agreement) (1 Januaray 1995), art 27(1) [TRIPs Agreement]. 
characterised as a State grant, with the element of discretion that such terminology implies. The reality, however, is that TRIPs limits the discretion of individual States as to whether to make a patent grant in a particular case.

Moreover, the State does not exist in a plane above patent rights. Article 28 of TRIPs, which details the minimum rights to be conferred by patents on the holder, does not explicitly provide that the patent holder must have the right to prevent the granting State itself from exploiting the invention that is the subject-matter of the patent. ${ }^{88}$ However, article 31 of the Agreement provides for strict conditions on State, or State authorised, use without the consent of the patent holder. In particular, the State must first have "made efforts to obtain authorization from the right holder on reasonable commercial terms and conditions", ${ }^{89}$ and in any case must pay the right holder "adequate remuneration in the circumstances of each case". 90 The grant of patent rights to an individual can therefore affect State activities as well as those of other individuals.

The potential for patent rights to interfere with the granting State's use is realised in the field of space utilisation. In Hughes $v$ United States of America, the government of the United States of America became embroiled in 20 years of litigation following the claimed infringement of a patent owned by the Hughes Aircraft Company. ${ }^{91}$ The patent, over "an apparatus for controlling the attitude of a spin-stabilized spacecraft" was used in the Galileo programme and over 100 other NASA space objects, including co-operative multilateral efforts. ${ }^{92}$ Ultimately, the government was found to have infringed the patent in a number of cases and ordered to pay damages. ${ }^{93}$ Similarly, in Fogarty $v$ United States of America, the plaintiff claimed government infringement of a patent over a magnetic docking mechanism. ${ }^{94}$

The combined effect of these provisions is to enable private individuals to, with effort, obtain patent rights over an invention that are enforceable within the jurisdiction of a large number of States and even against those States. Of course, this was to a certain extent possible before TRIPs. The real effect of TRIPs is to increase the relative power of the individual or State seeking the patent against the granting State to the point where the grant of a patent is arguably a relatively

88 TRIPs Agreement, above, art 28(1).

89 TRIPs Agreement, above, art 31(1)(a).

90 TRIPs Agreement, above, art 31(1)(h).

91 Hughes v United States of America (1993) 29 Fed Cl 197, Turner J.

92 Hughes $v$ United States of America, above, 204, Turner J. The Galileo craft was specifically designed to study Jupiter.

93 Hughes $v$ United States of America, above, 243, Turner J.

94 Fogarty $v$ United States of America (1984) $5 \mathrm{Cl} \mathrm{Ct} 402$. 
mechanical exercise. ${ }^{95}$ While it is dangerous to overstate the simplicity of achieving effective "universal" rights in practice, ${ }^{96}$ the position, in theory, is that States are effectively bound by their international obligations to issue patents and respect their terms.

It therefore open for an individual, or a particular State, to gain patent rights over a particular use of space that are enforceable against all space-faring States and all space-faring individuals. Moreover, the major space-faring nations, and therefore the States with the most important jurisdictions to have patent rights enforceable in, appear willing to facilitate this process. For example, the States Partners in the operation of the International Space Station agree to waive domestic laws regarding secrecy of inventions that would prevent simultaneous filing in another jurisdiction. ${ }^{97}$ This practice is no doubt founded in the desire to advance the investment of commercial interests in space development.

The effect of this law and practice is to undermine the communal nature of space. Essentially, the presence of TRIPs and the combined policies of space-faring nations that look favourably on patent rights over space-based inventions allows the theoretical conflict to manifest as a practical reality. An individual or State may now gain what amounts to effective monopoly rights over a particular use of the intrinsic properties of the space environment on a first come, first served basis, diminishing the free use of space by others. Simply put, space is therefore in practice no longer res communis, but rather is effectively a form of res nullius. The newly discovered "common well" of space, theoretically open to all the State "villagers" to use, is in fact having its use openly appropriated to individuals and particular States to the exclusion of others.

The potential consequences of this manifestation of the theoretical conflict is significant. Unlike use of that other common area, the high seas, "almost every aspect of space activity involves spectacular feats of ingenuity leading to frequent innovative discoveries". ${ }^{98}$ Space utilisation remains in the early stages of development; the discovery of particular uses of the space environment, such as crystal growth in microgravity, has largely occurred within the last 20 years. ${ }^{99}$

95 Thus, in the pharmaceutical controversy in Africa, the key issue is not whether pharmaceutical products can be excluded from patentability (clearly they cannot) but what power the State has under article 31 to grant compulsory licences. See, for example, "Ministeral Conference Declaration on the TRIPS Agreement and Public Health" (14 November 2001, Doha) WT/MIN(01)/DEC/2, arts 5(b)- 5(c).

96 See, for example, Christopher DeCluitt "International Patent Prosecution, Litigation and Enforcement" (1997) 5 Tulsa J Comp and Int'l Law 135.

97 Agreement Among the Government of Canada, the Governments of Member States of the European Space Agency, the Government of Japan, the Government of the Russian Federation, and the Government of the United States Concerning Co-operation on the Civil International Space Station (29 January 1998), art 21(3) <ftp://ftp.hq.nasa.gov/pub/pao/reports/1998/IGA.html> (last accessed 29 September 2002).

98 Ty S Twibell "Space Law: Legal Restraints on Commercialisation and Development of Outer Space" (1997) 65 UMKC LR 590, 616.

99 For example, see DeLucas "Protein Crystal Growth in Microgravity" (1989) 246 Science 651. 
There is, therefore, almost no body of common knowledge regarding the uses of space, beyond the mere fundamentals of space flight, that may be drawn on by the international community in their use of space. Almost every use of space will be novel and therefore capable of forming the subject matter of a patent. This is certainly a favourable prospect for industry and States interested in developing the commercial potential of space. Indeed, it is the prospect of significant quantities of commercially exploitable intellectual property rights deriving from the use of the intrinsic properties of space that underlies the development of the International Space Station. ${ }^{100}$ However, it also means that almost every new use discovered for the "common" area of space will be appropriated away from the international community for a minimum period of 20 years. ${ }^{101}$

Of course, none of this alters the legal position. International law is framed in terms of rights and obligations of individual States. In this case it is not a single State's unilateral application of domestic patent law to space-based activities that conflicts with the status of space as res communis, as defined by international law. Rather, it is the combined effect of a number of unilateral patent grants in the context of international obligations that essentially require such grants to be made. No one State is therefore "to blame" for undermining the status of space as a communal area, it is a truly supra-national problem.

No doubt the supra-national nature of the conflict also provides an explanation for why the practical manifestation of the theoretical conflict appears to have evaded commentators. The vast majority of commentary on space law comes from the United States, and in the last 10 years has been dominated with analysis of how best to move forward with the commercialisation of space given the continued presence of the United Nations' space treaties. ${ }^{102}$ The focus of such papers is whether the United States of America's unilateral application of its domestic patent laws is consistent with its international obligations. No attention has been paid to the wider international consequences of the combined effect of a number of States' actions to promote commercialisation of space.

100 Marguerite Broadwell "Intellectual Property and the Economic Development of the International Space Station" (Speech to the Space Technology and Applications International Forum, Albuquerque, February 2000) 2. <http://commercial.hq.nasa.gov/files/staifpapers/intellectual property.pdf $>$ (last accessed 29 September 2002).

101 Agreement on Trade Related Aspects of Intellectual Property Rights (Annex 1C, World Trade Organisation, Marrakesh Agreement) (1 January 1995), art 33.

102 See, for example, Ty S Twibell "Space Law: Legal Restraints on Commercialisation and Development of Outer Space" (1997) 65 UMKC LR 589; Leo Malagar and Mario Apalisok Magdoza-Malagar "International Law of Outer Space and the Protection of Intellectual Property Rights" (1999) 17 BU Int'l LJ 311; Jocelyn Shoemaker "The Patents in Space Act: Jedi Mind Trick or Real Protection for American Inventors on the International Space Station?" (1999) 6 J Intell Prop L 395, 420 ; Fred Kosmo "The Commercialisation of Space: A Regulatory Scheme that Promotes Commercial Ventures and International Responsibility" (1988) 61 S Cal L Rev 1005, 1067; Julie Jiru "Star Wars and Space Malls: When the Paint Chips Off a Treaty's Golden Handcuffs" (2000) 42 S Tex L Rev 155. 
Attention should be paid to the wider consequences, both by academic commentators and the international community. It is all very well for individual States' conduct to be legitimate, however if the effect of the current trend in granting patent rights over space-based inventions is to undermine the status of space as res communis, all States have a duty, a moral obligation erga omnes, to consider the consequences. The real danger of the practical conflict identified by this paper is that as the conduct of all States involved is legal, humanity will happily continue down the current path of conduct without any consideration of the potential effects.

As the problem is supra-national, so must be the solution. The author is not, here, making an argument against the grant of patents over space-based inventions. The grant of patents may no doubt be a good policy to stimulate private investment in an area that requires significant funding and whose development is to the benefit of all humanity. However it is doubtful whether unilateral State grants of monopoly privileges is an appropriate mechanism.

As has been noted previously in this paper, the grant of a patent monopoly and the terms and conditions on which that grant is made is essentially a matter of policy. The current trend of unilateral grants means that no co-ordinated international policy can be formulated to best promote the development of space technology; the patent holder is left with the terms and conditions resulting from a balance struck by a variety of States for domestic purposes, most likely without the particular policy objectives of granting patents over space-based activities in mind. The irony here is that the trend in unilateral patent grants, motivated by the perceived benefits of advancing commercialisation of space, may result in a balance that is not optimal for the very interests sought to be advanced. Certainly, in one respect this is the case. Although this paper has emphasised the universal nature of the bundle of patent rights able to be obtained by individuals over a space-based invention, it nonetheless remains a bundle of distinct rights. Thus, walking from the Japanese module to the European Space Agency module on the International Space Station may dramatically alter the legal rights sought to be enforced. This state of affairs undermines the legal certainty required by industry to invest in space activities. ${ }^{103}$ Thus, industry itself recognises a need to: ${ }^{104}$

achieve harmonisation of the use of [intellectual property rights] in space activities ... It seems the only hope for such a situation would be some sort of international legislation ... a uniform legislation must undoubtedly be proposed on a global level.

It is also worth noting what is being "bargained with" by States that make unilateral patent grants over space-based inventions to encourage investment in research and development of space activities. The State's "consideration" in the bargain with industry is "a limited-term exclusive right

103 B L Smith "An Industry Perspective on Space-Related Intellectual Property Rights" (September 1995) 15 ECSL News $<$ http://esapub.esrin.esa.it/ecsl/ecsl15/ecs115sm.htm $>$ (last accessed 29 September 2002).

104 Smith, above. 
to exploit the invention". ${ }^{105}$ Where the patent is over a use of space, this is a limited-term exclusive right to make use of the common area in a particular manner. It might be asked, how is this the granting State's to give? Again, if limits are to be placed on the use of a common area, it seems natural that the international community whose use is being restricted should assess the benefits of the bargain collectively. If an exclusive license is to be granted to a "common well", it seems more likely that an appropriate bargain will be struck if it is the "village" that makes the grant, rather than each individual "villager".

\section{CONCLUSION}

The development of the International Space Station ushers in a new era of exploitative private utilisation of space, where the major products of space use are intellectual inventions. In order to assure private investment in space development, it is necessary that these products are sufficiently protected from third party interference. The success of the commercialisation of space in this new era will therefore largely depend on the efficiency of the intellectual property protection available for industry. Nonetheless, regard should also be had to the status of space as a "common area". This status has been fundamental to the understanding of space use since humanity first entered space. As such, it cannot be lightly dismissed in the interests of commercialisation.

Subsequent State practice in the 30 years of space exploitation and the apparent intentions of the negotiators of the United Nations' space treaties indicate that the registry State may impose its laws on its space objects, even if those laws infringe upon individuals' free use of space. However, focusing on the actions of one State in asserting jurisdiction arguably misses the more subtle, and therefore arguably more dangerous, undermining of the communal nature of space caused by the combined effect of the actions of a number of States.

Given the unquestionable legality of the application of domestic patent laws to space-based activities, it is not "necessary" that any effort should be made by the international community to resolve the conflict identified by this paper. Nonetheless, an effort should be made. The author therefore joins the call from industry for a supra-national body to be created to legislate appropriately for an international patent regime specific to space-based inventions, albeit for somewhat different reasons.

105 Christopher DeCluitt "International Patent Prosecution, Litigation and Enforcement" (1997) 5 Tulsa J of Comp and Int'l L 135, 137. 